\title{
The use of oxygenated hydrocarbons in gasoline and their contribution to reducing urban air pollution
}

\author{
M.A. Mays \\ ARCO Chemical Europe Inc. \\ Bridge Avenue, Maidenhead, Berkshire, SL6 1YP, ENGLAND
}

\begin{abstract}
One of the most significant advances to occur in automotive fuel technology over the past ten years has been the use of oxygenated hydrocarbons in the pzoduction of gasoline. Whereas ten years ago essentially all transportation fuel was $100 \%$ petroleum-based, today it is safe to say that over $40 \%$ of all cars in West Europe and $25 \%$ of those in the United States, or roughly 100 million cars, are being driven on gasolines containing oxygenates.
\end{abstract}

This paper will briefly review the underlying reasons for oxygenated fuel use, the types and characteristics of the most common oxygenates, environmental benefits resulting from their use, and the outlook for the future.

\section{INTRODUCTION}

The current use of oxygenates began in the latter half of the 1970s when crude oil shortages developed and the search for alternative fuels began in earnest. Methanol, which could be produced from coal, and bio-ethanol from agricultural feedstocks were extensively evaluated as replacements for petroleum-based motor fuel. While neat alcohol use was blocked by the need for a separate fuel distribution system and specially designed vehicles, commercial blending of alcohols in gasoline began in 1979 in West Germany and in 1981 in the United States. Separately, Brazil embarked on a monumental program to convert all motor fuel to either neat ethanol or a $20 \%$ ethanol / gasoline blend.

\section{OXYGENATE USE}

Today, oxygenates are used by refiners not so much as a crude oil supplement but as an important and much needed source of octane. Octane demand has increased dramatically due to removal of lead anti-knock compounds from gasoline. Allowed lead levels in leaded gasoline are being reduced as recent medical evidence shows that current automotive lead emissions are a serious and costly health hazard (Refs. 1-4)

The United States has phased out lead use down to the $0.026 \mathrm{~g} / 1^{*}$ level. West European countries have reduced lead levels to $0.15 \mathrm{~g} / 1$ with the significant exceptions of France, Italy, Spain, and Portugal which currently allow lead up to $0.4 \mathrm{~g} / 1$. Reductions in these countries are expected as pressures mount to harmonize standards by 1992 . In fact, Italy has already announced their intention of reducing lead to $0.15 \mathrm{~g} / 1$ by 1991 (Ref. 5). In several urban areas, where higher lead levels are still allowed, the concentration of lead in the atmosphere currently exceeds the limit set by the EEC in 1982 ( 2 micrograms / cubic meter annual average) (Ref. 6).

Unleaded gasoline is another big factor driving octane demand. This is now being introduced in Europe to allow the reduction of vehicle exhaust emissions by means of catalytic converters. Unleaded gasoline introduction is proceeding in varying degrees in West European countries (Table 1). In the United States, with $80 \%$ of the market being unleaded, most of the increase in octane demand has already occurred. Octane demand is, however, increasing further by the introduction of higher octane premium unleaded grades.

* $1 \mathrm{~g} / 1=1 \mathrm{~kg} \mathrm{~m}-3$. 
Table 1 - Lead Use in Gasoline - by country

\begin{tabular}{|c|c|c|c|}
\hline Country & / Area & $\begin{array}{l}\text { Maximm Lead } \\
\text { Allowed in } \\
\text { Leaded Gasoline }\end{array}$ & $\begin{array}{c}\text { Unleaded } \\
\text { Gasoline } \\
\text { Per cent of } \\
\text { Total Market }\end{array}$ \\
\hline \multicolumn{4}{|c|}{ Europe: } \\
\hline & $\begin{array}{l}\text { France } \\
\text { Portugal } \\
\text { Spain }\end{array}$ & $0.40 \mathrm{~g} / 1$ & $\begin{array}{l}<1 \\
<1 \\
<1\end{array}$ \\
\hline & Italy & $\begin{array}{lll}0.30 \mathrm{~g} / 1 & \text { Apr } & 89 \\
0.15 \mathrm{~g} / 1 & \mathrm{June} & 91\end{array}$ & \\
\hline & Austria & & 29 \\
\hline & Belgium & & $<1$ \\
\hline & Denmark & & 30 \\
\hline & * Finland & & $<1$ \\
\hline & $\begin{array}{l}\text { Greece } \\
\text { Ireland }\end{array}$ & & $<1$ \\
\hline & Luxemburg & $0.15 \mathrm{~g} / 1$ & $<1$ \\
\hline & * Netherlands & & 20 \\
\hline & Norway & & 18 \\
\hline & Sweden & & 28 \\
\hline & * Switzerland & & 27 \\
\hline & * United Kingdom & & $<1$ \\
\hline & West Germany & & 27 \\
\hline \multicolumn{2}{|c|}{ United States } & $0.026 \mathrm{~g} / 1$ & 80 \\
\hline \multicolumn{2}{|l|}{ Japan } & - & 100 \\
\hline
\end{tabular}

In West Europe, octane demand will continue to grow rapidly, with most of the increase coming in the Mediterranean countries. Fig. I shows projected octane demand in motor octane number of the clear gasoline pool (MON* clear) for Northern and Southern Europe.

The most common oxygenates used today are Methyl Tertiary Butyl Ether (MTBE) (IUPAC nomenclature: 2-methoxy-2-methylpropane). Methanol/Tertiary Buty1 Alcohol (TBA) (IUPAC nomemclature: 2-methy1-2-propanol blends and Ethanol. MTBE is widely used in both Europe and the United States while Ethanol is confined to the American States that subsidise

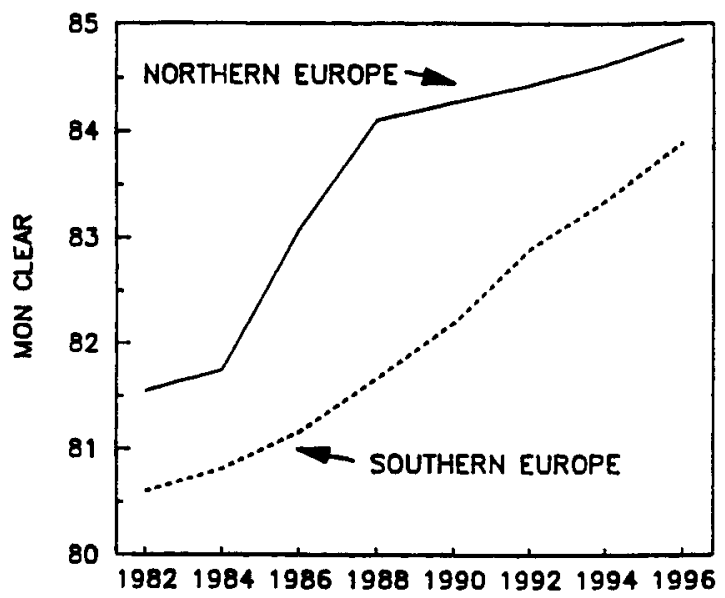

Fig. 1 Octane demand European refining industry

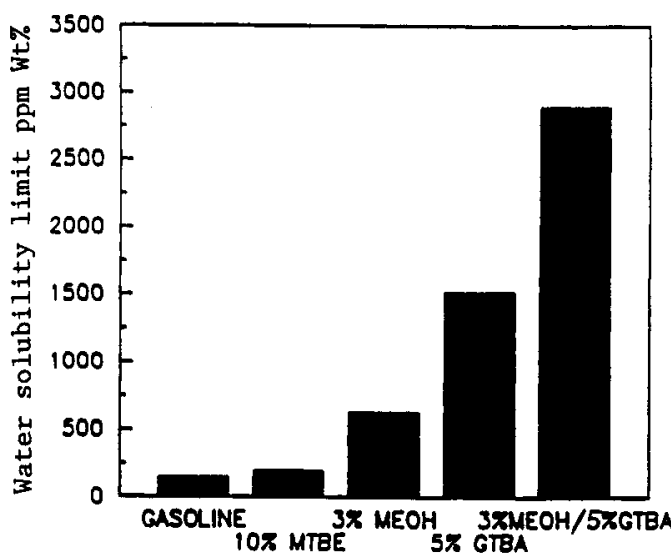

Fig. 2 Water tolerance of selected oxygenates (at $0^{\circ} \mathrm{C}$ )

* MON = Refer to GLOSSARY OF TERMS at the end of document. 
Table 2 - Typical Properties of Commonly Used Oxygenates (Compared To Gasoline)

\begin{tabular}{|c|c|c|c|c|c|c|}
\hline & \multicolumn{2}{|c|}{ Blending Octanes } & \multirow{2}{*}{$\begin{array}{l}\text { Blending } \\
\text { RVP / Bar }\end{array}$} & \multirow{2}{*}{$\begin{array}{l}\text { Blending } \\
\text { Density } \\
/ \mathrm{g} \mathrm{cm-3}\end{array}$} & \multirow{2}{*}{$\begin{array}{c}\text { Distillation } \\
/{ }^{\circ} \mathrm{C}\end{array}$} & \multirow{2}{*}{$\begin{array}{l}\text { Oxygen } \\
\text { Content } \\
I \text { Wt } z\end{array}$} \\
\hline & Ron* & Mon & & & & \\
\hline MTBE & 118 & 101 & 0.55 & 0.740 & $51-74$ & 18 \\
\hline TRA & 109 & 94 & 0.70 & 0.755 & $74-95$ & 22 \\
\hline $\begin{array}{l}\text { Methanol / } \\
\text { TBA }\end{array}$ & 121 & 97 & 2.30 & 0.774 & $74-84$ & 40 \\
\hline Gasoline & $92-98$ & $82-88$ & $0.6-1.1$ & $0.74-0.78$ & $28-215$ & 0 \\
\hline
\end{tabular}

agricultural Ethanol production. The most significant use of Methanol / TBA blends today is in Austria and West Germany. Volumetric concentrations used are typically $0-15 \%$ for MTBE, 3-5\% for methanol, 3-7\% for TBA, and $5-10 \%$ for ethanol. MTBE is the most commonly used oxygenate and enjoys the fastest growth due to its superior blending properties and greater physical similarity to gasoline hydrocarbons.

\section{SELECTED PROPERTIES OF OXYGENATES}

The key property of any oxygenate is its octane blending value (Table 2). This can vary according to the composition of the gasoline components with which it is blended. Other important properties include vapour pressure, distillation, specific gravity, oxygen content and, for alcohols, the water solubility properties.

Methanol practically cannot be blended without a higher alcohol "cosolvent" such as TBA, IBA, SBA, or IPA (isobutyl alcohol, sec-butyl alcohol and isopropyl alcohol: IUPAC nomenclature 2-methy1-1-propanol, 2-butanol and 2-propanol). Otherwise, methanol would be extracted as soon as the gasoline came in contact with water, which is a common occurrence in most distribution systems. Cosolvent alcohols increase the water solubility of gasolines containing methanol and increase the equilibrium concentration of methanol in the gasoline phase, should the solubility be exceeded (Fig. 2 and 3 ).

The solubility of water in gasolines containing ethanol is usually high enough not to require a cosolvent. For any alcohol use in gasoline extensive precautions must be taken by refiners to avoid any excessive contact with water during the manufacture or distribution of the product.

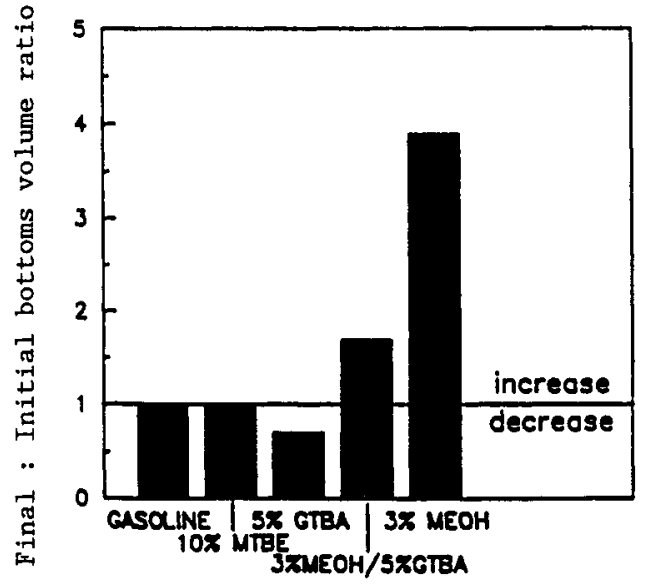

Fig. 3 Single water extraction test data with fuels containing oxygenates

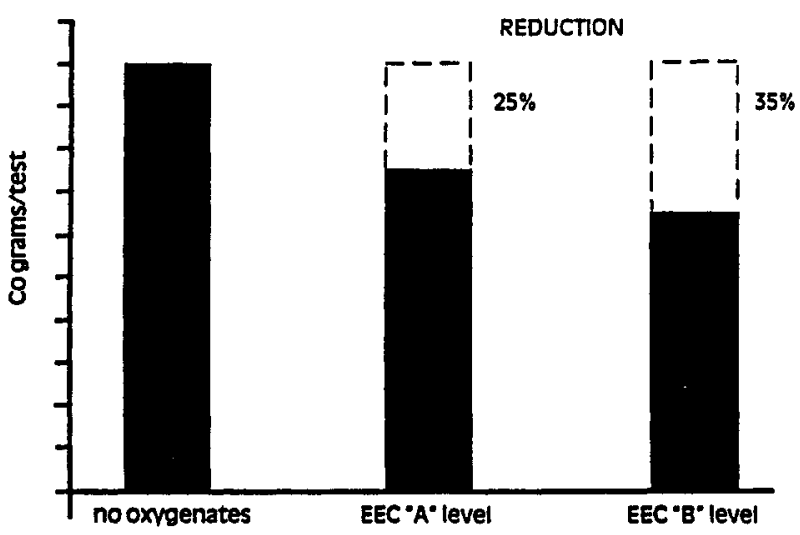

Fig. 4 CO-exhaust emission reduction with oxygenates

$*$ Ron $=$ Refer to GLOSSARY OF TERMS at the end of document. 


\section{ENVIRONMENTAL BENEFITS}

While oxygenates initially were considered as a crude oil supplement and today are mainly used for their octane value, future use will be strongly environmentally driven. Perhaps the most important benefit of using oxygenates, even today, is the contribution they make to reducing air pollution.

Oxygenates have a positive environmental impact in four major areas:

1. Lead use can be reduced due to the octane contribution.

2. Vehicle carbon monoxide emissions are reduced by $25-30 \%$.

3. Vehicle benzene emissions are reduced by $15-20 \%$.

4. The photochemical reactivity of evaporated hydrocarbons are reduced.

Carbon Monoxide - Motor vehicles typically account for over $90 \%$ of the carbon monoxide in urban atmospheres. Approximately $75 \%$ of of the total pollutants found in motor vehicle exhaust are, in fact, CO (Refs. 7-9).

Due to the leaning effect on the engine air to fuel ratio, oxygenates reduce vehicle $\mathrm{CO}$ emissions by roughly $25 \%$ when used at the 2.5 weight \% oxygen level (Fig. 4). This reduction is basically a function of oxygen content and is independent of oxygenate type (Refs. 10-13). For some engines, hydrocarbon exhaust emissions are also reduced. NOx emissions, on average, remain unchanged (Fig. 5) (Ref. 14-18).

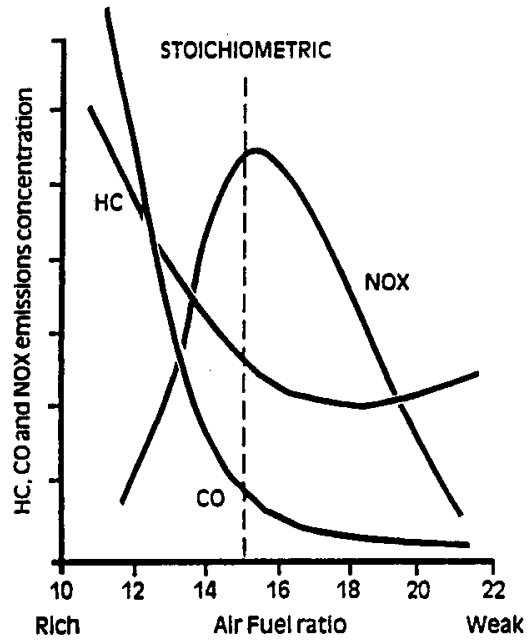

Fig. 5 Exhaust emissions vs Air-Fuel ratio

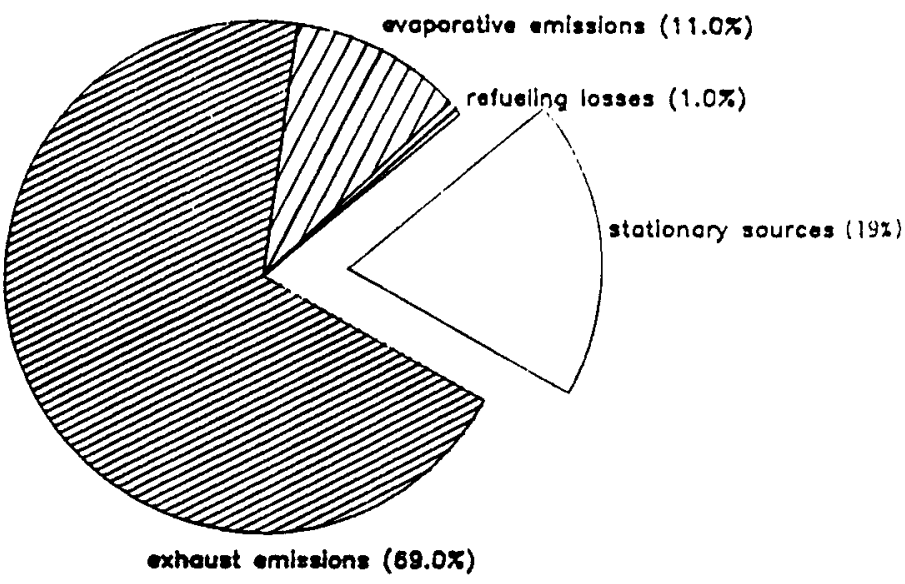

Fig. 6 Sources of atmospheric benzene (West Germany)

In the United States, several States are developing legislation that will mandate a minimum level of oxygen in all gasolines sold in market regions that currently exceed federal CO standards (Refs. 19-20). Colorado and Arizona already have legislation in place requiring all gasoline to contain a minimum of 2 weight $\%$ oxygen during the winter months, when $C O$ levels are their highest.

The higher emissions of the European car population coinpared to those of the United States make the $C O$ reducing properties of oxygenates even more significant here. For the same percentage reduction, the total quantity of $C O$ reduced can be far greater in Europe and other regions which have less restrictive emission controls.

Benzene - As lead is removed from gasoline, a major environmental concern is that refiners will increase reforming severity to make up for lost octane. This would resuit in increased amounts of aromatics in gasoline, including benzene which is a known carcinogen (Refs. 21-22). Current ERC legislation sets a maximum benzene level of 5 volume \% in unleaded gasoline (Ref. 23). Lower levels of 3 volume \% , or less, are currently being considered in West Germany. California is now proposing to reduce the average benzene content to 0.6 volume $\%$ in the early $1990 \mathrm{~s}$.

Typically, 80 to $90 \%$ of all benzene found in the atmosphere comes from gasoline powered motor vehicles (Fig. 6). For Buropean vehicles, 857 of the the total benzene emitted is from the exhaust. Evaporative and refuelling losses make up the remainder (Ref. 24). 


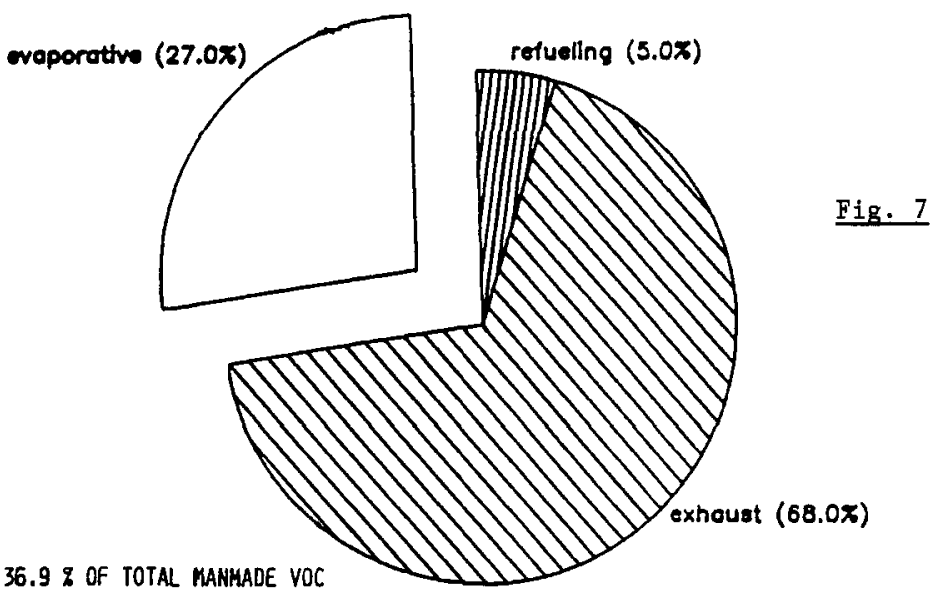

VOC emissions from gasoline vehicles (Western Europe)

$36.9 \%$ OF TOTAL MANMADE VOC

Even with no benzene in a gasoline other aromatics, such as toluene, have been found to increase motor vehicle benzene emissions (Ref. 25).

Oxygenates used instead of reformates to provide octane can significantly reduce benzene emissions. For example, MTBE used at 10 volume \% can reduce aromatic levels by as much as 6 volume per cent. This can result in a $12 \%$ reduction of benzene in the vehicle exhaust, regardless of whether or not the vehicle is equipped with a catalyst.

Photochemical Pollution - In addition to the exhaust emission reductions, oxygenates can also produce benefits with regard to vehicles' evaporative emissions. In West Europe $27 \%$ of vOC (volatile organic compounds) emitted from gasoline powered motor vehicles is in the form of evaporated fuel (Fig. 7) (Ref. 26). This relative contribution will increase as stricter exhaust emission legislation comes into effect. Of all the components used in gasoline, a comparison between studies that rank atmospheric reactivity of individual compounds shows oxygenates to have some of the lowest oxidation rates (Ref. 27).

Since oxygenates displace other hydrocarbons in the fuel vapour phase, the implications are that evaporative emissions from gasolines blended with oxygenates will probably contribute to a reduction in smog build-up in the atmosphere (Ref. 28).

\section{CONCLUSION}

Oxygenated compounds have an important role to play in the transportation fuel sector, offering:

1. A reduced dependency on imported crude oil.

2. A cost effective source of octane, which is required to produce low-lead and unleaded gasoline.

3. Significant reductions in several key motor vehicle pollutants.

The use of oxygenates in gasoline will continue to grow driven by octane demand, particularly in Europe, and for environmental reasons, particularly in the United States.

\section{GLOSSARY OF TERMS}

MTBE - METHYL TERTIARY BUTYL ETHER (2-METHOXY -2-METHYLPROPANE)

RON - RESEARCH OCTANE NUMBER (AGTM D-2700)

TBA - TERTIARY BUTYL ALCOHOL (2-METHYL-2 PROPANOL)

MON - MOTOR OCTANE NUMBER (ASTM D-2700)

MEOH - METHANOL (METHYL ALCOHOL)

RVP - REID VAPOR PRESSURE (EN12)

IBA - ISOBUTYL ALCOHOL (2-METHYL-1-PROPANOL)

EEC - EUROPEAN ECONOMIC COMMUNITY

SBA - SEC-BUTYL ALCOHOL (2-BUTANOL)

IPA - ISORROPYL ALCOHOL (2-PROPANOL) 


\section{REFERENCES}

1. US EPA, Costs \& Benefits of reducing Lead in Gasoline, Washington DC (1984).

2. D. Bryce-Smith - Chemical Society Review, 15, 93-123 (1986).

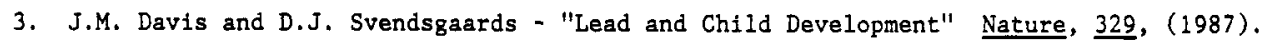

4. Report to the Swedish Government from the National Insitute of Environmental Medicine, Motor Vehicles \& Cleaner Air - Health Risks resulting from Exposure to Motor Vehicle Exhaust, (1983).

5. Varato Dal Consiglio Die Ministri, (1988), Il Decreto per la Benzina senza Piombo, Staffetta Quotidiana Petrolifera, (1988).

6. EEC Directive No $82 / 884 / \mathrm{CEE}$, (1982).

7. M.P. Walsh - Global Trends in Motor Vehicle Air Pollution Control SAE Paper No 850383.

8. M.L. Williams - Warren Springs Laboratory - The Science of the Total Environgent 59, 47-61 (1987)

9. C.J. Potter and C.A. Savage - A Survey of Gaseous Pollutant Emissions from Tuned In-Service Gasoline Engined cars over a Range of Road Operating Conditions, Warren Springs Laboratory, Dept. of Industry, UK, LR 447 (AP) M.

10. F.H. Palmer - Vehicle Performance of Gasoline containing Oxygenates, BP, I Meche, C319/86, (1986).

11. Emission Test for Vehicles fuelled with various Fuels Containing Oxygenates, ARCo Chemical Europe Inc/UTAC Study (1983).

12. M. Sposini et a1, Engine Performance \& Water Tolerance Of Gasoline Containing The Alcohol Mixture Obtained By The Snamprogetti Process, Assoreni, 5 th International Alcohol Fuel Technology Symposium (1982).

13. Oxygenated Fuels Association - Alcohol Based Octane Enhancers, Submitted to the Committee on Commerce, Science \& Transportation of The United States Senate, (1985).

14. Commission of The European Community, Report of the Ad Hoc Group ERGA II - Air Pollution, Part 2; Section 3; Report of WG3. Consumers \& Environment; Doc. $\mathrm{XI} / 100 / 84-\mathrm{EN}$, VF.

15. American Petroleum Institute - Alcohols - A Technical Assessment of their Application as Fuels, (1976).

16. R.L. Furey and J.B. King, Emissions, Fuel Economy \& Driveability effects of Methanol/Butanol Gasoline Fuels Blends, SAB Paper No 821188 .

17. Atlantic Richfield Co., Submission to the Environmental Protection Agency by Atlantic Richfield Co. for a waiver to the Clean Air Act, Section 211 (F), (1981)

18. B.M. Wathne and O. Hov, Environmental Impact of Methanol as a Motor Vehicle Fuel, Norwegian Institute of Air Research, (1985).

19. Washington Bulletin, NPRA (1987).

20. G. Gallagher, Statement of The Colorado Department of Health, Air Pollution Control Division, Oxygenated Fuels Programme, presented at the 2nd EFOA Conference (1987).

21. Air Resources Board \& Department of Health Services - Report to the Scientific Review Panel on Benzene, California (1984).

22. United States Department of Health Services, National Toxicology Programme - Third Annual Report on Carcinogens, Washington DC, (1982).

23. CEN Unleaded Gasoline Specifications; EN 228.

24. J.M. Tims, Benzene Emissions from Passenger Cars, Concawe, (1983).

25. D.E. Seizinger et al, Vehicle Evaporative \& Exhaust Emissions As Influenced by Benzene Content of Gasoline, National Institute for Petroleum \& Energy Research; SAR 860531 .

26. Concawe; Position Paper - Gasoline Vehicle Evaporative Emissions.

27. F.C. Chanslor, An Opportuntty for $\mathrm{CO}$ \& Benzene Emission Reductions from Mobil Sources - Environmental Impact of Methanol Cosolvent Alcohol Gasoline Blends used by The Refining Industry as an Octane Source, Celanese Chemical Co. Inc.

28. J.M. Dejovine, Emission System Durability with Methanol Blended Gasoline, ARCo Chemical Co., 7 th International Symposium on Alcohol Fuels, (1986). 